\section{Israel rules on medical confidentiality}

The Israeli health ministry has issued guidelines to all the country's health workers detailing how to ensure confidentiality of medical information about their patients. The rules form the backbone of a government sponsored bill of hospital patients' rights, which is due to be passed by the Knesset (Israel's parliament).

The guidelines were prepared by the health ministry's director general, Dr Meir Oren, who sent the document to all public and private hospitals and clinics. Previously, principles were open to interpretation by health workers and patients alike. Punishment for violating confidentiality did not refer specifically to health workers but to all public employees. The new law will contain punishments for violators, including prison sentences and loss of professional licences.

"The document is important not only because it says what is permitted and what is forbidden but also because it will boost workers' awareness of how important protecting the privacy of patients is," says Dr Yitzhak Berlovich, the ministry's director of medical services.

Most medical files in Israel are not yet computerised. Dr Berlovich says: "Perhaps this is fortunate as the risk of medical information reaching the wrong eyes is greater when it is put on line. But the irreversible trend here and around the world is to store medical data on computers and to connect them via telecommunications links. We have a five year plan to carry this out, and an integral part of the project will be ensuring that only those who treat a patient will be able to see these data."

In his guidelines Dr Oren defined as confidential information any objective data about a patient's health or life and any subjective information passed confidentially to the health worker. However, if the patient consents to the transfer of certain information to specific people or institutions this does not violate confidentiality rules. If staff want to pass on information to a patient's relatives the patient must agree. If the patient is unconscious or legally incompetent, doctors should not give the family any more information than is objectively needed for the patient's benefit.

Exceptions to the new rules include patients with a notifiable infectious disease or a condition that precludes driving or possession of a weapon; cases where there is a suspicion of violence or harm to minors or helpless people; and patients who have expressed an intention to commit a crime. In these cases, the information must be transferred to the relevant authority, such as the police, the cancer registry, or the district health office.- JUDY SIEGEL-ITZKOVICH, medical correspondent, ferusalem Post

\section{Correction}

Seascale cancer cluster not due to radiation

An author's error occurred in the news item by Fiona Godlee (6 April, p 865). The item reported that there had been no new cases of leukaemia in Seascale since a sewage treatment works was set up in 1984. It should have stated instead that there have been no new cases of leukaemia and lymphoma among young people who were born since 1984

\title{
Focus: Sydney
}

\section{Greiner does a Thatcher}

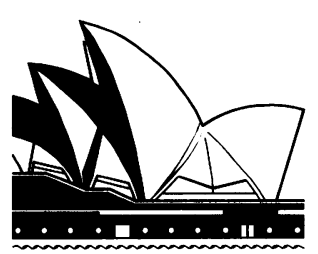

WD and HO Wills, British American T o b a c c o's Australian subsidiary, recently announced the appointment of $\mathrm{Mr}$ Nick Greiner as chairman of its board. Greiner was Liberal premier of New South Wales in 1988-92 and resigned from politics after being criticised by a body of his own creation, the Independent Commission against Corruption, after allegations that he had acted inappropriately in assisting a rebel member of his party to leave politics.

Greiner's rush to embrace the tobacco industry-like that of Margaret Thatcher, who took up work as a consultant for Philip Morris after leaving politics-comes as little surprise. As premier he regularly railed against tobacco control ("The range of things that has been done around Australia ... may be philosophically repugnant in terms of the impact on the rights of individuals").

Wills has just suffered a loss of $\$ A 5.2 \mathrm{~m}$ $(£ 2.6 \mathrm{~m} ; \$ 3.9 \mathrm{~m})$ in 1995 as its share of a record $4.8 \%$ annual national decline in tobacco consumption, so Greiner's attractions are considerable. He maintains a role as a power broker in the Liberal Party and is philosophically close to the new prime minister, John Howard.

Both indulge in anti-nanny state rhetoric about tobacco, although Howard promised that he would not wind back Australia's tough smoking control policies if elected.

In 1992 all three federal political parties voted for a total ban on tobacco advertising, which took full effect at the beginning of 1996, when Benson and Hedges' sponsorship of cricket ended. Nevertheless, the federal minister for health may exempt international events if removal of the event is threatened. Naturally, such threats are now made regularly. While still in power, two successive Labor health ministers granted exemptions for grand prix car and motorcycle racing and for Australia's challenge for the Americas Cup yacht race. Similarly, New South Wales' Labor health minister, Dr Andrew Refshauge- known for concerns about addressing inequity and workers' health-has exempted motor sports heavily patronised by blue collar smokers and their children.

The prime minister promised not to raise tobacco tax in his first parliamentary term, a move that Greiner and his board would relish. Howard seems certain to be no less adroit in holding the door open for an increasing number of "international events" to deck themselves out with tobacco advertising. It is not difficult for the organisers of essentially local events to link them to an international circuit and invite participants from abroad.

The undisguised reliance on the argument that Australia will lose lucrative sporting events to other countries if it were to be serious about a total ban on advertising reveals how far tobacco control must travel before such expediency would be considered political suicide. It is unthinkable that a parallel argument could be sustained over infant formulas, for example: that the ban on promoting them should be broken because other nations were doing so.

Action on Smoking and Health (ASH) is currently gathering evidence about the 1985 campaign that successfully lobbied to have "smoking is addictive" suppressed as warning on cigarette packets. In view of the current investigations in the United States into whether tobacco company chiefs committed perjury by swearing to Congress that nicotine was not addictive, tobacco control agencies in Australia are wondering whether $\mathrm{Mr}$ Greiner will be prepared to toe his parent company's line and make a similar declaration.

Nick Greiner does not smoke himself-a phenomenon not uncommon among tobacco executives. Doubtless he would argue, as do others in his industry, that he chooses not to smoke. While the male head of a lingerie company would not be expected to "choose" to wear women's underwear, smoking is a choice open to all. It is scarcely imaginable that the chairman of Ford would drive a Toyota or the head of the Meat Marketing Board be a vegetarian. Such lack of personal confidence in their products would probably see them not long in their jobs. The tobacco industry does not seem to mind such hypocrisy. - SIMON CHAPMAN, associate professor of public health and community medicine, Sydney. 